\title{
Türk İnkılabı ve Türk Modernleşmesi Sürecinde Yurt İçi ve Yurt Dişı Gözlemler (1923-1938)
}

\author{
DOI: $10.26466 /$ opus.498340 \\ * \\ Mustafa Kilınç \\ * Dr. Öğr. Üyesi, Amasya Üniversitesi Eğitim Fakültesi Amasya / Türkiye \\ E-Posta: sosyaltite@hotmail.com \\ ORCID:0000-0001-8436-2874
}

\section{Öz}

Türkiye Cumhuriyeti Devleti'nin temelleri Amasya Tamimi, Erzurum ve Sivas Kongrelerinde atılmıştır. Mustafa Kemal Atatürk önderliğinde Türk Halkı birbirine kenetlenerek bir bütün oluşturmuştur. 1923'te cumhuriyetin ilanıyla beraber Türk Inkılap Hareketleri; sosyal, siyasi, ekonomik ve toplumsal alanda hızlı bir şekilde başlamıştır. Yeni kurulan bu devlet Yeni Türkiye Devleti olarak isimlendirilmiştir. Devlet, Kemalizm ideolojisinde gerçekleşmiştir. Buradaki Kemalizm ideolojisi; modernleşme ve gelişme anlamlarında kullanılmıştır. Kemalizm ideolojisinin temelinde Atatürk'ün inşa kabiliyeti, girişkenliği ve itidalli davranışlar yeni oluşumun başarı sırrıdır. Diğer bir ifadeyle yeni bir devlet kurma, bunu yaparken aktif olma, gerçekleştirmek istediği olayların uygun zamanını bekleme yeteneğidir. Yeni Türkiye Devleti'nin inşası için inkılap tarihi dersleri adı altında hukuk, dış-iç siyaset ve ekonomi konferansları CHP'nin etkili isimleri kanalıyla verilmiştir. Türk İnkllap hareketi Anadolu Yaylası'nda parlamış ve kendine has başkalığı olan inkılap hareketi olmuştur. Bu yenilik ve inkılapların bir tanesi de yurt genelinde etkili olan halk evleridir. Yeni devletteki yaşanan gelişmeler hem yurt içi hem de yurt dışında dikkat çekici olmuştur. Bu gelişmeler yurt içi ve yurt dışı basınında yer bulmuştur. Bu dönemde özgün demokratik gelişmeler yaşanırken dönemin tek partisi CHP ile devletin ideolojisi aynı olmuştur.

Anahtar Kelimeler: Yeni Türkiye, Türk Inkılabl, Türk Modernleşmesi, Kemalizm 


\title{
Domestic and Foreign Observations during Turkish Revolution and Turkish Modernisation (1923-1938)
}

\begin{abstract}
Foundations of Turkish Republic were formed in Amasya Circular, Erzurum and Sivas Congresses.Turkish Public were unified in the leadership of Mustafa Kemal Atatürk.Turkish Revolution, launched through declaration of Turkish Republic in 1923, encompassed social, political, economical and societal fields.This new state was called as New Turkish Republic. The state had its roots in Kemalism Ideology.In this sense, Kemalism Ideology refers to modernization and development.The entrepreneurship skill of Atatürk, founder of Kemalism Ideology, and calm bevahiors underpin the success of new state initiatives.Said another way, building a new state is the ability of being active and patient to be able to determine the best time to act. Law, domestic and foreign policy and economical conferences under the name of Revolution History courses were provided through prominent membes of Republican People's Party $(\mathrm{CHP})$ in order to establish New Turkish Republic. Turkish Reform Movement has its roots in Anatolia Plains and has become a unique reform movement. Public houses were one of the most effective revolutions of these reforms.New developments that occured in newly-established state took attention both inside and outside the country. These developments were included in the newspapers in domestic and foreign countries. While unique democratic movements originated in this period, CHP, the only political party, shared the same ideology with the new state.
\end{abstract}

Keywords: New Turkey, Turkish Revolution, Turkish Modernisation, Kemalism 


\section{Giriş}

"İdeoloji: Siyasal veya toplumsal bir öğreti oluşturan bir hükümetin, bir partinin, bir gurubun davranışlarına yön veren politik, hukuki, bilimsel, felsefi, dini, moral, estetik düşünceler bütünü." (TDK) Bu bağlamda Kemalizm ideolojisi nedir? Kemalizm bir ideolojidir ancak nasıl bir ideoloji olduğuna dair farklı görüşler mevcuttur. Kemalizm'i bazıları; modernleşme, gelişme, batılılaşma, çağdaşlaşma, devrimci gibi sözcüklerle ifade etmektedirler. Yurt içi ve yurt dışında birçok ilim adamının ortak düşüncesi Kemalizm ya da Atatürkçülük; yenileşmeyi, gelişmeyi, çağdaşlaşmayı öngören bir ideoloji olduğu konusunda hemfikirdir. Atatürkçülük ya da Kemalizm Türk Modernleşmesinin dışa yansımasıdır. Kemalizm'in tanımlamalarda farklılık olduğu gibi içerik konusunda da farklı değerlendirmeler mevcuttur. Bu da Kemalizm'in yoruma açık özelliğinden kaynaklanmaktadır. Bu kavram yurt içi ve dışında farklı yorumlanmaktadır.

"Uluslararası literatürde, Kemalizm ya da Atatürkçülüğ̈̈n üç temel kavramı vardır. Bunlar: 1-Türkiye'de çoğunlukla benimsenen şekliyle Atatürkçülük ya da Kemalizm, Türkiye'nin 1920'lerdeki devriminin ideolojisidir.2-Dış ülkelerde Kemalizm'in daha geniş boyut ve çağrışımları vardır ve çoğu kez bir gelişme modeliyle eş anlamda kullanılmaktadır.3-Siyasal gelişmelerde ordunun oynadığı rolü inceleyen bilimsel araştırmalarda ise daha dar bir anlamda kullanılmaktadır. Bazen genç uluslarm askeri liderlerinin hepsinin uygulaması gereken eşsiz bir yönetim modeli pretoryanist olarak tanımlanmaktadır. Bazen de toplumlarda halkla ordu arasında ideal ilişkiler modeli, ya da en gelişmiş askeri yönetim biçimi olarak nitelendirilmektedir (Turan,1996, III, s.30-33). Bu ifadelerden de anlaşılacağ1 üzere Kemalizm kavramı farklı farklı yorumlanırken kavramın da soyut olduğu göze çarpacaktır. Bu çalışmada Kemalizm, modernleşme ve gelişme anlamlarında kullanılmıştır.

Devleti oluşturan unsurlar; egemenlik, vatan, millet ve siyasi teşkilattır. Ama devletin en önemli özelliği devleti kurmada önderlik eden lideriyle halkın lider etrafında çelikleşen varlığıdır. Bu bağlamda Türkiye Cumhuriyeti Devletini var eden, Mustafa Kemal Atatürk ile Atatürk'e inanan ve onu destekleyen Anadolu Halkıdır. Bu devletin temeli, liderinin ismiyle özleşerek Kemalizm ideolojisi olmuştur. Yeni kurulan Türkiye Cumhuriyeti Devleti'ne yaşama ömrü olarak on yıl gibi kısa bir süre 
biçenler bugünlerde yeni devletin medeniyet yolunda var oluşunun yüzüncü yıl kutlama gururuna şahit olmaktadırlar.

\section{Türkiye Cumhuriyeti Devleti'nde Kemalizm'in Yeri}

Türkiye Cumhuriyeti Devleti, yok olamaya ramak kalan bir toplumun yaşama tutunma mücadelesini kazandığı süreçtir dersek haksızda sayılmayız. Türkiye Cumhuriyeti Devleti karşısındaki bütün engelleri tek tek ortadan kaldırarak dimdik ayakta kalabilen Türk toplumunun eseridir. Türk halkı örfünü, geleceğini kurtarmak için birçok acılar çekmiş vatanı için şehitler vermiştir. Mustafa Kemal Atatürk önderliğinde var olma mücadelesi veren Türk toplumu kısa sürede bütün düşmanlarına Türkleri hiçbir gücün yok edemeyeceği göstermiştir.

Türk Halkı devleti için Atatürk'ün etrafında tek bir kişi gibi beraber olmuşlardır (İnönü, Ulus, 12 İlkkanun 1935). Bu bağlamda Türk Milleti yükselişini ve istiklalini milli birliğine borçludur (Nabi, Ulus, 5.09.1936). Hanrf'ye göre Yeni Türkiye'de eskisi kadar Rum ve Ermeni kalmamış ancak Türk yani Moğolistan ve Mançurya' nın kardeşi eski Tatar ırkı ile fethi takip eden Bizanslılarla kan karışmasından doğma bir Türk ırkı kalmıştır (Hanrf, Ulus, 06.03.1936). Yabancı yazarın cümlesindeki vurgu; yeni kurulan devlette eskisi kadar azınlık vatandaşların kalmadığıdır. Türklerin en büyük eseri devletiydi. $O$ da bütün büyük eserler gibi hayatın akışına uygun bir ilerlemeyle yenileşmeli ve kuvvetlenmeliydi (Peker, Ulus Gazetesi, 3 Temmuz 1936). Bu büyük eserin adı Türk devrimiydi. Türk Devrimi, gelişigüzel olayların sıralanması değildir. Türk Devrimi rastgele olaylar silsilesi olmayıp bir anlam bütünlüğü olan harekettir. Türk Devrimi evrensel bir olaydır (Peker, Ulus,18 İlkkanun 1935). Türk devrimi Kemalist Türkiye diye de adlandırılabilir. Kemalist diplomasi kaynağını Amasya Tamimi, Erzurum ve Sivas kongrelerinden almıştır. Yeni devlet, diğer bir ifadeyle yurt içi ve yurt dışı siyasetini Amasya Tamimi, Erzurum ve Sivas Kongrelerinde ön plana çıkan düşüncelerden almıştır. Kemalizm'in hem teorik bazları hem pratik metotları mevcuttu. Bunlar; Millet menfaatlerinin tarif ve tayininde taviz tanınmaz (teorik baz), daima realist olmak (pratik metotlarda) dünyayı ve davanın malzemesini kusursuz tetkik etmek, iyi hazırlanmak, davayı olgun hale getirmek, müdahalenin anını kollayarak anında müdahale etmek gibi metotlardı (Belge, Ulus, 19 
Nisan 1936). Gözlemcilere göre Yeni Türkiye Devleti, Kurtuluş Savaşı'nı yukarıda ifade edilen Kemalizm ideolojisinde gerçekleştirmiştir. Bu ideolojiyi de oluşturan Mustafa Kemal'in kendisiydi. Burada vurgulanmak istenen Kemalizm'in modernleşme ve gelişme anlamlarında mimarının Mustafa Kemal olduğudur. Kemalizm ideolojisini oluşturan Mustafa Kemal'in üç temel yeteneği vardı. Matematik bilgisiyle inşa kabiliyeti, girişkenliği, bilim adamının olgun itidaliydi_(Ulus Gazetesi, 29 Sonteşrin 1935).

\section{II.Türkiye Cumhuriyeti Devleti'nde Gelişme}

Atatürk önderliğinde kurulan Türkiye, bütün hareketlerinde tasfiye ile beraber yeni inşayı da amaç edinen bir devlet olmuştur (Belge, Ulus Gazetesi, 24 Mart 193). Kemalizm milliyetçiliği ve medeniyetçiliği içinde Asyalı ve Afrikalı iptidailik yoktu (Atay, Ulus, 11 Haziran 1936). Kemalist rejim huzla ilerlemesine rağmen Atatürk döneminde inşa halinde olmuştur. Türkiye bu dönemde Avrupa'dan Asya'ya modern tekniği ve kültürü, Asya' dan Avrupa'ya da milletler arsında yeni bir köprü olmuştur (Belge, Ulus, 7.02.1936). Bu köprü görevi Kemalizm demokrasini doğurmuştur. Kemalizm demokrasisi ihtilal ve milli bütün şartların eseridir. "Ülkemizdeki demokrasi, milli birliği ve bütünlüğü en fazla sağlayan ve milli faaliyetlerin verimini en çok artıran usulleri ve şekilleri arayarak ve hürriyetin anarşiye doğru, otoritenin zora ve keyfe doğru tefsirlerini reddederek var olmuş ve gelişmiştir" (Atay, Ulus, 28.03.1937). Bu bağlamda Kemalizm her şeyden önce bir kültür ve medeniyet hareketi olmuştur (Belge, Ulus, 28.02.1937).

Yeni Türkiye'de Kemalizm hareketini toplum geneline öğretmek için İnkılap Tarihi dersleri uygulamaya konmuştur. İnkılap Tarihi dersleri ilk başlarda CHP'nin önemli isimleri tarafından konferans şeklinde verilmiştir. Konferans konuları arasında gruplamada; dış siyaset, siyaset, iktisat ve hukuk bulunmaktaydı. Konferanslarda; dış siyaset konuları Yusuf Hikmet (Bayur), siyaset konuları Recep Peker, ekonomi konuları Yusuf Kemal (Tengirşek), hukuk konuları Mahmut Esat (Bozkurt') a görev verilmişti. $\mathrm{Bu}$ derslere devam etmeyen öğrenciler okuldan muzun olamıyordu. İnkılap Tarihi dersleri bu süreçle başlarken 1960 sonrası ismi 
Türk Devrim Tarihi adıyla devam etmiş tekrar 1980 sonrası yeni düzenlemeyle Atatürk İlkeleri ve İnkılap Tarihi adıyla okutulmuştur (Bakacak, 2014).

İnkılap derslerinde kavratılmaya çalışılan ana düşünce ise şöyleydi; “Türk İnkılabı, Türk Milleti'nin milli siyasal, sosyal, kültürel, ekonomik yaşayışına, dişla münasebetine tesirler yaparak müstakil millet halinde bir yeniden var olma hareketidir. İnklabın birbirinden ayrı să̆-sol temayülleri yoktur. Inkılabın bütün ileri săg, ileri sol temayülleri tasfiye ederek bir millet yapma, milli devlet kurma temayülü vardır." "Türk inkllabı hürriyet inkılapları tipinden bir inkllap olarak isimlendirilebilir. Buradaki isimlendirme tasnif bir ideolojiyi birliğinin mevcut oluşuna değil idare edilenlerden idare edenlere karşı bir harekettir. Türk inkılabı Türk Milleti'nin yaşama iradesinden doğmuştur. Türk inkılabı dünya inkılapları arasinda olmakla beraber bunlarm en ilerisinde yabancı bütün inkılap anlayışlarının dışında, yepyeni bir dünya, yepyeni bir millet ve yepyeni bir devlet anlayışının öncüsüdür"(Atay, Ulus, 13 Sonkanun 1936). Türk inkılabı geri kalmış toplumlara, ileri toplumların kendi aralarındaki yaşantısına tesirler yapmada model olmuştur ve geri ve ileri toplumların birbiriyle ilişkilerine etki yapmıştır. Türkiye'de tek parti oluşu Türk inkılabının devlet idaresinde aşama aşama gerçekleşmesini sağlamıştır (Atay, Ulus Gazetesi, 14 Sonkanun 1936). Bu düşünceler 1şığında; “Türk devrimi, dă̆ tepelerinde tutuşup ufku baştan başa aydınlatan ateşler gibi, Anadolu Yaylası'nda parlamıs ve kendine has başkalığı olan bir olay olmuştur" (Tekin, Ulus, 24 Ağustos 1936).

Türk devriminin yerleşmesini sağlayan en büyük unsur ise eğitim olmuştur. Bu doğrultuda; 1924 Tevhidi Tedrisat kanunuyla Türkiye Avrupa tarzında modern tedrisata başlamış oluyordu. Yeni eğitim bünyesi, Türkiye'ye modernleşmede ivme kazandırmıştır. Yedi bin mekteple ilk okullara giden öğrenci sayısı 1923-1924'te 341.941 iken 1937 'de 600 bin olmuştur. 1923'te 9bin 972 öğretmenden ancak yarıs öğretmen mektebinden mezun iken 1937'de 13000 öğretmenin yarısından fazlası öğretmen mektebi mezunu olmuştur. Geri kalanları ise lise veya buna denk okullardan mezundu. 1937'de yaklaşık 100 orta mektep ve 40 lise bulunmaktaydı. 1923-1924'te beş bin 905 öğrenci 1937'de 42 bin 500 olmuştur (Hryy, Ulus, 20.03.1937). 1933'te 200 binden fazla insan halk mekteplerine devam etmiştir. Halk evleri vasıtasıyla halk eğitimi yurdun dört bir tarafına yayılmıştır (Hryy, Ulus, 21.03.1937). Bunlarla beraber 
halkevleri cumhuriyetin en fazla övündüğü yeniliklerden olmuştur (Sovaj, Ulus, 18 Ağustos 1935). 1932'de 34 iken 1933'te 21 1934'te 25, 1935 'te 23, 1936' da 33, 1937' de 31 olmak üzere toplam 167 halk evi mevcut olmuştur (Atay, Ulus, 21.03.1937).

1914 yılında 3000 olan okul sayısı 1935'te 7000'ne öğrenci sayısı da 230 binden 500 bine yükselmiştir.1928'de 700 bin olan okuma yazma bilenlerin sayısı 1935'te üç milyona çıkmıştır (Sovaj, Ulus, 11 Ağustos 1935). Savaşlar sonrası anne babasını kaybeden yetimler de unutulmamıştır. Avrupa dahi hiçbir memlekette yetim meselesi Türkiye'de olduğu kadar önem verilmemiştir. Bu bağlamda Himayeyi Etfal Cemiyeti kurulmuştur. Başlangıçta elbise, kundura, ilaç ve süt dağıtan yaklaşık 130 şube varken 1935'te kreşler, poliklinikler ve sütnine okullarıyla sayıları 500'den fazla olmuştur (Sovaj, Ulus, 18 Ağustos 1935.)

Kemalizm hareketi bir taraftan eğitimle öğretilmeye çalışlırken diğer taraftan teknolojik yatırımlarla da Yeni Türkiye modernleşme yolunda hızlı adımlarla ilerliyordu. 1923-1933'e kadar hükümet ülkede demiryolları ağının gelişmesine çok önem vermiştir. Rusya'dan sonra Avrupa'nın en geniş toprakları olan Anadolu'da yeniden 20 bin km demiryolu yapılmıştır. Başlangıçta 130 tane olan türlü fabrikalar rastgele çoğaldı ve bunların sayısı 1933'te 2500'ü geçti. Sümer Bankın kapitali 20 milyon liradan 62 milyona çıkarılmıştır. Beş yıllık kalkınma planının uygulanmasında Sümerbank ön planda olmuştur. Devlet her yıl Sümerbank'a altı milyon lira ayırmıştır (Sovaj, Ulus, 16 Ağustos 1935).

Yeni Türk Hükümeti'nin gayesi ülkede en kısa zamanda; sosyal, ekonomik ve kültürel alanlarda gelişme sağlamak olmuştur (Sovaj, Ulus, 8 Ağustos 1935). Rejim için en sağlam yol devletçilik ve planlamay1 merkeze almak olarak görülmüştür. Plan: Devlet ve halk kuvvetlerini toplu çalıştırmak, ulusal enerjiyi tam verimli ve değerinde tutmaktır (Atay, Ulus, 13.05.1935). "Türk inkılabının ateşli enerjisinden sarih olarak çıkan, Türk Milletinin herhangi bir müze mumyasının donmuş ve ölmüş hayatına asla razı olmadığı ve olamayacağıydı. Ülkenin ekonomik olarak gelişmesi Kemalist Programm en esasl ve en önemli noktalarndan biriydi. Çünkü Avrupa'ya bağh bir ülkede tam kültürel ve siyasi istiklale kavuşması imkansızdı" (Walter, Ulus, 20 Sonkanun 1937). Türkiye'de devlet demir yollarının millîleştirilmesi, Latin alfabesinin kabulü en önemli değişim unsurlarındandı (Tageblat, Ulus, 21 Ağustos 1935). Bu gelişmelerle beraber 
tarım ve hayvancılığa da ağırlık verilmiş hayvancılığı geliştirmek için Avrupa'dan damızlıklar getirilmiştir. Ulaşım hizmetlerinde altı bin köprü ve geçit yapılmıştır. Yolların uzunluğu 12 bin km'den 40 bin $\mathrm{km}$ ye çıkarılmıştır. Sağlık alanlarında sıtma azaltılmış trahomla mücadelede önemli gelişmeler sağlanmıştır (Sovaj, Ulus, 14 Ağustos 1935). 1.Dünya Savaşı'ndan önce 100 bin ton buğday 150 bin ton un ithal eden Türkiye 1936'da bunlar ihraç eden ülke konumuna gelmiştir. 1935'lerde Türkiye'de görülmemiş bir şekilde değişmiştir. Kırılmaz bir enerji, muti, çalışkan ve kanaatkâr, bir milleti idare etmiş ve onu verimli ve faal bir hayata varlığını koruyabilme imkanın sunan bir mükemmeliyete doğru götürmüştür (Alfred, Ulus, 22.03.1936).

\section{Türkiye Cumhuriyeti Devleti'nin Temel İlkeleri}

"Eskisini temeline kadar yıkan hız ve ateş, yenisini çatısına kadar kuran yaratıcı bir enerji olarak kullanıldığı zamanda; uluslar yalnız tarih değil, ülkenin olumsuz durumunu da değiştirmiş olurlar" (Atay, Ulus Gazetesi, 23.04.1935). “Bu bağlamda CHP'nin doğuşu ve ilerleyişi yurdun kurtuluşuna ve yeni Türkiye Devleti'nin kuruluş ve ilerleyişine bağgl, onun içinde ve onunla beraber var olan bir hadisedir" (Ulus Gazetesi, 14.05.1935). Gözlemciye göre; Türkiye Devleti politikasının temeli, Cumhuriyet Halk Partisi'nin 1927'de Ankara'daki kongresinde belirtilen; cumhuriyetçiyiz, milliyetçiyiz, halkçıyız, devletçiyiz, laikiz, inkılapçıyız sözleri esasındadır (Ulus Gazetesi, 08.05.1936).

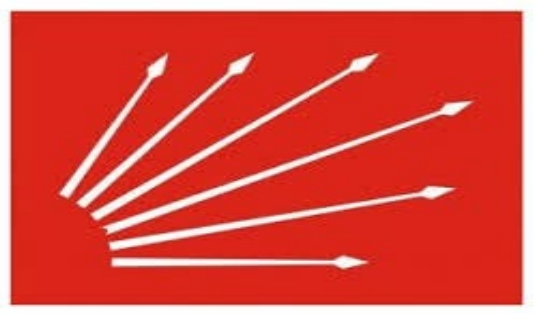

Diğer bir ifadeyle, dönemin tek partisi Cumhuriyet Halk Partisi'nin ana prensipleri Türkiye Cumhuriyeti'nin kanuni ifadesidir (Belge, Ulus, 10.05.1936). Esasta partinin ana vasıfları olan cumhuriyetçilik, ulusçuluk, halkçılık, devrimcilik, devletçilik ve laiklik Türkiye Devleti'nin de vasıflarıdır (Ulus Gazetesi, 14.05.1935).

CHP'nin 6 oku büyülü bir formül gibi gözükse de 6 okun temeli; modernleşme, laikleşme, Batı'nın kültürüne, bilimine ve teknolojisine dayanan bir ideolojik yapısı vardır. Kemalizm ya da Atatürkçülük söz konusu 
olduğunda 6 okun sayısını azaltma ve çoğaltma bilimsel ilkelere aykırıdır. Fakat araştırmacı ele aldığı konuyu yorumlama ve eleştirmede özgürdür. $\mathrm{Bu}$ ilkeler soyut olduklarından, uygulamada döneme ve kişilere göre farklılık bulunması kaçınılmazdır (Turan,1996, s.33-34).

Sovaş Atatürk Türkiye'si başlıklı gözleminde; "altı okun uzunlukları birbirinden farklıdır. Cumhuriyetçiyiz ilki en kısadır. Ondan sonra altıncısı geliyor devrimciyiz, sonra ikincisi ulusçuyuz beşincisi laikiz, üçüncüsü halkçıyız nihayet en sonunda en uzun olan devletçiyiz. Hemen şunu söyleyeyim ki model sahibinin bunu hiç düşünmemiş olduğuna inanıyorum. Fakat tesadüf beni ikna etti ki Yeni Türkiye'nin prensipleri arasinda büyüklük sırası varsa, oklarm büyüklükleri buna en fazla yaklaşandır. Bundan sonra yaptığım müşadeler pek de buna zıt çıkmadr." (Sovaj, Ulus, 8 Ağustos 1935) Gözlemcinin bu cümlesinden çıkaracağımı sonuç ise şudur: Sovaş'a göre Türkiye'de 6 okun uygulamaları 1923-1938 döneminde farklı olmuştur Sovaj'ın gözlem sırası(soldan sağa oklar)bakımından sırayla şu şekilde ifade edilebilir; 1-Cumhuriyetçilik 2Milliyetçilik (Ulusçuluk) 3-Halkçılık 4-Devletçilik 5-Laiklik 6-İnkılapçılık (Devrimcilik)

Diğer taraftan bu ilkelerden laiklik ilkesinde, Türkiye laikleşmiş olmakla beraber en kuvvetli İslam devleti olarak kalmıştır (Georges, Ulus, 19 Şubat 1936). Yeni Türkiye devletçi ve milliyetçilik ilkeleri bağlamında da diğer devletlerin haklarına önem vermiştir (Ulus Gazetesi, 13.05.1936). “Türkler Dünya'nın en müsamahalı en uzlaşıcl, en az kin tutan ırkıdır. Bu özelliklerinden dolayı Türkiye en yakın zamana ait eski can düşmanları ile kolaylıkla ve samimiyetle dostluk tesis edebilmişlerdir" (Ulus Gazetesi, 08.05.1936). Bu durumla ilgili olarak 18.asırdan 1936'lere kadar boğazlar üzerine hakimiyet için didişen Rusya ve İngiltere Türkiye'nin barışçı politikalarına inanarak antlaşma sağlamışlardır (Atay, Ulus, 27 Temmuz 1936). Yeni Türkiye'de bu süreçler yaşanırken demokraside ivme kazanmıştır. Türk demokrasisinin özünde demokrasinin halk tarafından halk içindir anlayışı hâkim olmuştur. Yeni Türkiye'de demokrasi bir ruh bir espri ve mana olarak görülmüştür. Yapılan işler akıl süzgecinden geçirildikten sonra bölgenin kültür ve yapısına uygunsa kabul görmüştür. Türkiye'nin demokrasi anlayışı taklit ya da özenti olmayıp ulus ve memleket yapısına uygun, özgün bir demokrasi anlayışıdır (Ulus Gazetesi, 14.05.1935). 


\section{IV.SONUÇ}

Yurt içi ve yurt dışı gözlemcilerin açıklamaları incelendiğinde; Türkiye Cumhuriyeti Devleti, 1923-1938 döneminde köklü değişikliklerden geçerek kendine has kurumsallaşma yolunda ilerleme sağlamıştır. Bu gözlemler devletin modernleşme ve gelişmesi temelinde, Kemalizm olarak isimlendirilmiştir. Kemalizm'in yorumlanabilme özelliğinden dolayı bu gözlemcilerin fikirleri, kendine özgü bütünlüğü olan yargilardir.

Türkiye Cumhuriyeti Devleti, Mustafa Kemal Atatürk'ün inşa kabiliyeti, girişkenliği ve yenilikleri gerçekleştirmek için uygun zamanı bilmesi ile Türk Milleti'nin vatan, millet ve özgürlük adına her türlü fedakarlığ1 yaparak Mustafa Kemal'in etrafında tek yürek olmasıyla inşa edilen bir devlettir. Yeni Türkiye Devleti belirli ideoloji etrafında kendine has özellikleri olan bir devlettir. Türkiye Cumhuriyeti inkılap hareketleriyle medeniyet yolunda ilerlerken yapılan inkılaplar birbirini tamamlar nitelikte bir eserdir. Bu eser evrensel özeliklere sahiptir. Yeni devletin temellerini Amasya Tamimi, Erzurum ve Sivas Kongreleri oluşturmuştur. Türkiye Cumhuriyeti Devleti 1923-1938 yıllarında büyük oranda oluşumunu tamamlamakla beraber bu dönemde henüz kuruluş aşamasında kalmıştır. Atatürk Dönemi tek partili yıllar olup bu bağlamda inkılap hareketlerinin topluma benimsetilmesi CHP ile olmuştur. Bu gelişimlerle beraber yeni devlet, Atatürk ilkelerinden laikliğe büyük önem verirken diğer taraftan gelenek ve dini değerleriyle barışık olmayı başaran bir toplum olmuştur. Bu toplum kendine has demokratikleşme hareketleriyle modernleşmede varlığını göstermeye devam etmektedir. 


\title{
EXTENDED ABSTRACT
}

\section{Domestic and Foreign Observations during Turkish Revolution and Turkish Modernisation (1923-1938)}

\author{
Mustafa Kilınç
}

Amasya University

Ideology: A cohesive set of political, judicial, scientific, philosophical, religious, ethical and aesthetical ideas that gives a direction to the behaviors of a group, a party or a government which form a political and societal doctrine. In this sense, Kemalism is an ideology but there are some controversies what kind of ideology it is. Some attempt to clarify it as a modernization, development, westernization, revolutionist movement. However, a growing number of scientists both in inside and outside have come to an agreement about the definition of Kemalism. They define it as an ideology that represents innovation, development and modernization. Kemalism is a reflection of Turkish Modernisation. On the other hand, there are some different opinions about the content of Kemalism as it is in its definition. This is due to the fact that it doesn't pose any boundaries but set people free to think about new ideas. The concept is approached from different perspectives in inside and outside of the country. In international literature, Kemalism is based on three basic concepts: (1) Kemalism represents Turkish Reforms in 1920s in Turkey. (2) In outside of Turkey, Kemalism is perceived as a modernization model and holds a broader meaning. (3) Kemalism is addressed through a narrower meaning in scientific research that examines its role in political developments and and army's role. In this regard, it is sometimes defined as a unique management praetorianistic model that must be adopted by military leaders in new established states. On the other hand, it is conceptualized as an ideal relations model between public and army or a developed militaristic managerial model. Based on these considerations, it can be noted that Kema- 
lism is addressed from different perspectives and it holds an abstract nature in itself. In this study, Kemalism refers to modernization and development.

The components of a state can be listed as sovereignity, homeland, public and political system, but the most important one is that the presence of a strong and unified society with a leader. In this sense, what makes Turkish Republic as a sovereign and independent state is that Anatolia People who believe in Mustafa Kemal Atatürk. The foundations of this state is based on Kemalism ideology. Those who thought that this new established state would only have a ten-year life span take pride in celebrating the 100th Anniversary of Turkish Republic. In this sense, we can summarize this study in two dimensions. The first one is that foundations of Turkish Republic were formed in Amasya Circular, Erzurum and Sivas Congresses.Turkish Public were unified in the leadership of Mustafa Kemal Atatürk.Turkish Revolution, launched through declaration of Turkish Republic in 1923, encompassed social, political, economical and societal fields.This new state was called as New Turkish Republic.The state had its roots in Kemalism Ideology.In this sense, Kemalism Ideology refers to modernization and development.The entrepreneurship skill of Atatürk, founder of Kemalism Ideology, and calm bevahiors underpin the success of new state initiatives.Said another way, building a new state is the ability of being active and patient to be able to determine the best time to act. Law, domestic and foreign policy and economical conferences under the name of Revolution History courses were provided through prominent membes of Republican People's Party (CHP) in order to establish New Turkish Republic. Turkish Reform Movement has its roots in Anatolia Plains and has become a unique reform movement. Public houses were one of the most effective revolutions of these reforms. New developments that occured in newly-established state took attention both inside and outside the country. These developments were included in the newspapers in domestic and foreign countries. While unique democratic movements originated in this period, CHP, the only political party, shared the same ideology with the new state.

Another emphasis made in the study is by domestic and foreign observers who put forward ideas on Turkey. Foreign writer Sovaş is one of the 
most prominent observers from outside the country. The lengths of six arrows in Sovaş's observation called as Atatürk's Turkey are different from each other. We are republican is the shortest one, followed by the sixth arrow, we are reformists. We are nationalist comes the second, while we are secular is the third, followed by we are populist. Finally, we are in favor of state is the longest one. At this precise point, it must be noted that the owner of the model hadn't ever thought about this. However, it is a coincidence that if there are some differences among New Turkey's principles, then they must be the lengths of the arrows. In this regard, the conclusions I made didn't contradict with inference. The result that can be drawn from the observer is that the implementations of six arrows in Turkey between 1923-1938 took place differently. The observation order of Sovaş can be listed as (from left to right arrows): (1) Republicanism, (2) Nationalism, (3) Populism, (4) Statism, (5) Laicite, (6) Revolutionism. In this regard, when the explanations of Sovas and other observants are examined, it can be seen that Turkish Republic made considerable improvements, undergoing radical changes between 1923-1938. These observations were called as Kemalism in terms of modernization and developments. The statements made by the observers are distinctive interpretations due to the nature of Kemalism. Turkish Republic is a state that was established by Turkish Nation with the devotion of Mustafa Kemal Atatürk as well as his entrepreneurship and clear sighted. New Turkish Republic is also a state that owns unique features. The reforms made was in nature that completed each other while Turkish Republic was moving ahead. This new state has universal patterns. Turkish Republic was in the process of development even though remarkable developments were achieved between 1923-1938. Atatürk period was the one in which one political party was dominant and the adoptation of reforms were made by CHP. Together with these developments, the new state has placed great importance on the principles of Ataturk and secularism, on the other hand it has become a society that has succeeded in being at peace with its religious and religious values. This society continues to show its existence in modernization with its own democratization movements. 


\section{Kaynakça / References}

Alfred C. (1936, 22 Mart). Ulus. s. 4.

Atay, F, R. (1935, 13 May1s). Planlı Türkiye. Ulus. s. 1.

Atay, F, R. (1935, 23. Nisan). Yirmi üç nisan. Ulus. s. 1.

Atay, F, R. (1937, 21 Mart). İnkılap terbiyesi. Ulus. s. 1.

Atay, F, R. (1936, 27 Temmuz). Yeni Türkiye ve rolü. Ulus. s. 1.

Atay, F, R. (1936, 11 Haziran). Medeniyetçilik cephesi. Ulus. s. 2.

Atay, F, R. (1937, 28 Mart). Siyasi müsteşarlar. Ulus. s. 1.

Atay, N. (1936, 13 Sonkanun). İnkılap dersleri Recep Peker. Ulus. s. 2.

Atay, N. (1936, 14 Sonkanun ). İnk1lap dersleri Recep Peker. Ulus. s. 2.

Bakacak A. (2014). Kemalizmi tarif etmek ya da inkılap tarihi dersleri. 3.

Uluslararası Tarih Eğitimi Sempozyumu. Sakarya: Türkiye. Ebook. S. 50-55.

Belge, B. (1936, 19 Nisan). Kemalist diplomasi. Ulus. s. 2.

Belge, B. (1936, 24 Mart). Yapici Kemalizm. Ulus. s. 2.

Belge, B. (1936, 7 Şubat). Türkiye ortada. Ulus. s. 2.

Belge, B. (1936, 10 Mayıs). Peker'in inkılap dersi. Ulus. s. 7.

Belge, B. (1937, 28 Şubat). Halk evleri. Ulus. s. 2.

Georges B. (1936, 19 Şubat). Ulus, s. 4-6.

Hanrf L. (1936, 6 Mart). Kemal Atatürk'ün memleketinde (Revve de France Gazetesinden). Ulus.

Hanrf, L. (1936, 6 Mart). Kemal Atatürk'ün memleketinde. Ulus. s. 4.

Hryy, H. (1937, 20 Mart). Türkiye'de kültür. Ulus. s. 4.

Hryy, H. (1937, 21 Mart). Türkiye'de kültür. Ulus. s. 4.

Hryy, H. (1937, 20 Mart). Türkiye'de kültür (Current History Dergisi). Ulus.

İnönü, İ. (1935, 12 İlkkanun). Ulus. s. 1.

Nabi, Y. (1936, 5 Eylül). Mili birliğin kıymeti. Ulus. s. 2.

Peker, R. (1936, 3 Temmuz). Ulus. s. 1.

Peker, R. (1935, 18 İlkkanun). 2. İnkılap dersini dün verdi. Ulus. s. 1-3.

Sovaj, M. (1935, 18 Ağustos). Bir Fransız gözüyle yeni Türkiye. Ulus. s. 2. Sovaj, M. (1935, 11 Ağustos). Bir Fransız gözüyle yeni Türkiye. Ulus. s. 4. Sovaj, M. (1935, 18 Ağustos). Bir Fransız gözüyle yeni Türkiye. Ulus. s. 2. Sovaj, M. (1935, 16 Ağustos). Bir Fransız gözüyle yeni Türkiye. Ulus. s. 4. Sovaj, M. (1935, 8 Ağustos). Bir Fransız gözüyle yeni Türkiye. Ulus. s. 4. 
Sovaj, M. (1935, 14 Ağustos). Bir Fransız gözüyle yeni Türkiye. Ulus. s. 4. Sovaj, M. (1935, 8 Ağustos). Bir Fransız gözüyle yeni Türkiye. Ulus. s. 4. Tageblat, N, W. (1935, 21 Ağustos). Ulus. s. 2.

Tekin, A. (1936, 24 Ağustos). Kemalizm. Ulus. s. 4.

Turan, Ş. (1996). Türk devrim tarihi, 3.Kitap. Ankara: Bilgi Yayınevi, Türk Dil Kurumu

Walter, LW. (1937 20 Sonkanun). Romans ve inkılap. Ulus. s. 6. (1935, 14 Mayıs). Bay Recep Peker'in söylevi. Ulus. s. 1.

(1936, 08 Mayıs). Atatürk Türkiye'sinin hakiki yüzü Türkiye'nin planlı politikası. Ulus. s. 4.

(1936, 13 Mayıs). Şehrimizden geçen Amerikalı bir terbiyeci B. Hugk Vernon White. Ulus.

(1935, 29 Sonteşrin). Yeni Türkiye ve önderi. (Volkişer Beobackter Gazetesi 12.11.1935 tarihli sayısindan). Ulus.

(1935, 29 Sonteşrin). Yeni Türkiye ve Önderi. Ulus. s. 4-5.

\section{Kaynakça Bilgisi / Citation Information}

Kılınç, M. (2019). Türk inkılabı ve Türk modernleşmesi sürecinde yurt içi ve yurt dişı gözlemler (1923-1938). OPUS-Uluslararası Toplum Araştırmaları Dergisi , 10(17), 2078-2092. DOI: 10.26466/ opus. 498340 